\title{
Isolated idiopathic central hypothyroidism in an adult, possibly caused by Thyrotropin Releasing Hormone (TRH) deficiency
}

\author{
Alma Prieto-Tenreiro', Patricia Diaz-Guardiola ${ }^{2}$ \\ ${ }^{1}$ Endocrinology and Nutrition Service, University Clinical Hospital of Santiago de Compostela, ${ }^{2}$ Endocrinology and \\ Nutrition Service, Infanta Sofía Hospital, Madrid, Spain
}

\begin{abstract}
Central Hypothyroidism (Central $\mathbf{H}$ ) is mainly due to acquired lesions, either in the pituitary, the hypothalamus or both, and in such cases it is usually associated with deficient secretion of other pituitary hormones. Isolated central hypothyroidism (I Central H) remains a very rare disease. By the use of the serum Thyroid Stimulating Hormone (TSH) assay as an initial screening test for thyroid disease, the diagnosis of $\mathrm{I}$, Central $\mathrm{H}$ can be missed or delayed, since most of these patients have normal or even slightly high serum TSH concentrations. We present a 54-year-old woman with intense tiredness, in whom hypothyroidism was initially and persistently excluded because of normal TSH levels. Further investigations showed again a normal TSH with slightly low Free Thyroxine (FT4), and Central H was suspected. A Thyrotropin Releasing Hormone (TRH) stimulation test confirmed the diagnosis. No lesion was found by Magnetic Resonance Imaging (MRI). No other pituitary hormone insufficiency was detected. Finally, after excluding, the intake of any drug affecting the hypothalamo-pituitary-thyroid axis and the presence of critical systemic illness, the unusual diagnosis of idiopathic isolated Central $H$ was made. When suspecting Central $H$, both FT4 and TSH should be measured and if these values are low, TSH response to TRH is recommended to reach specific diagnosis.
\end{abstract}

Key words: Central Hypothyroidism, Idiopathic secondary hypothyroidism, Isolated TSH deficiency, TRH test

\section{INTRODUCTION:}

Hypothyroidism is a common disorder. However,

Address for correspondence:

Alma Prieto-Tenreiro, Servicio de Endocrinología y Nutrición,

Hospital Clínico Universitario de Santiago de Compostela,

Travesía de la Choupana s/n, 15706 Santiago de Compostela,

Spain, Tel.: +34 620782333, Fax: +34 981952246,

e-mail: almaprietotenreiro@gmail.com

Received 20-09-09, Revised 10-12-09, Accepted 20-01-10 the overwhelming majority of patients with hypothyroidism have thyroid disease (primary hypothyroidism, $\mathrm{PH})$. Central hypothyroidism is defined as hypothyroidism due to insufficient production of $\mathrm{TSH}$, caused by hypothalamic or pituitary defect. Although the exact prevalence of Central $\mathrm{H}$ is unknown, it is much lower than that of $\mathrm{PH}$. Furthermore, patients with Central $\mathrm{H}$ frequently present with other pituitary hormone deficiencies, while isolated deficiency of 
TSH is very rare. Hashimoto ${ }^{1}$ noted in his review that approximately sixty cases of isolated TSH deficiency had been reported since Shuman's first report in $1953 .{ }^{2}$ Although in general practice serum TSH is the best indicator for detecting hypo- and hyperthyroidism and for monitoring treatment of thyroid disorders, this approach only works if the hypothalamic-pituitary-thyroid axis is normal. Consequently, by using TSH determination alone, patients with isolated Central $\mathrm{H}$ are usually missed.

We present a 54-year-old woman who presented with extreme tiredness. Hypothyroidism was suspected but it was initially excluded because of normal TSH in screening. On re-evaluation, Free Thyroxine (FT4) was low and the possibility of isolated TSH deficiency was suspected.

\section{CASE REPORT}

A 54-year-old woman was referred to our clinic for a two-year history of progressive and extreme tiredness (she had even stopped working), very low energy, exhaustion after physical exercise and weight gain of $18 \mathrm{~kg}$. She had no relevant family or personal past medical history, apart from menopause symptoms for which she had been on hormone replacement therapy (HRT) for the last 18 months. Reportedly, the TSH levels carried out several times by her general practitioner were normal.

On physical examination she presented very dry skin. The body mass index was $30.5 \mathrm{~kg} / \mathrm{m}^{2}$ and the blood pressure was normal $(105 / 68 \mathrm{mmHg})$. Initial investigations showed normal values of serum electrolytes, urea, liver function tests, calcium and cortisol. The insulin-like growth factor (IGF-1) was low (9.22 $\mathrm{nmol} / \mathrm{L}$, normal range 10.5-35). The FT4 was also low $(0.86 \mathrm{ng} / \mathrm{dl}$, normal range $0.9-1.8)$. The Free Triiodothyronine (FT3) was $2.69 \mathrm{pg} / \mathrm{ml}$ (normal range: 2.3-4.3), TSH was $1.34 \mathrm{mIU} / \mathrm{L}$ (normal range 0.35-5.5) and the thyroxine-binding globulin and the thyroid peroxidase antibodies (TPO) were also within the normal range. The endocrine profile was repeated after discontinuing the HRT for 6 weeks. A low IGF-1 $(8.5 \mathrm{nmol} / \mathrm{L})$ and a low FT4 $(0.87 \mathrm{ng} / \mathrm{dl})$ with a normal FT3 $(2.8 \mathrm{pg} / \mathrm{ml})$ were detected. As there was no TSH compensatory rise (TSH: $1.46 \mathrm{mIU} / \mathrm{L}$ ), and on the suggestion that she could have a pituitary cause for her hormonal deficiency, an MRI scan of the hypothalamic pituitary region was carried out, which revealed no abnormality. The rest of the pituitary function and a short Synacthen test were also normal. A thyrotropin releasing hormone (TRH) test was also performed. After 200 micrograms of TRH, a delayed response of TSH was found (Figure 1) (TSH at time 0: $2.3 \mathrm{mIU} / \mathrm{L}, \mathrm{TSH}$ at $30 \mathrm{~min}: 3.4 \mathrm{mIU} / \mathrm{L}, \mathrm{TSH}$ at 60 $\mathrm{min}: 36.2 \mathrm{mIU} / \mathrm{L}$ ), indicating a possible hypothalamic defect, in the absence of a structural abnormality in the MRI. An insulin tolerance test carried out after starting thyroxine treatment showed an adequate response of cortisol and growth hormone. Finally, on the basis of these results, a diagnosis of isolated TSH deficiency was made. The patient was started on 100 micrograms of thyroxine/day and now, one year later, she is feeling well and she is clinically and biochemically euthyroid.

\section{DISCUSSION}

Central hypothyroidism denotes thyroid hormone deficiency due to a disorder of the pituitary and/or hypothalamus. The etiology of central hypothyroidism is the same as for hypopituitarism. ${ }^{3}$ Pituitary mass lesions, especially pituitary adenomas, remain the most frequent causes of Central $\mathrm{H}^{4}$ accounting for more than half of the cases. Traumatic brain injury ${ }^{5}$ or subarachnoid hemorrhage, bexaroteno (a retinoid X receptor agonist $)^{6}$ therapy, maternal Graves' disease ${ }^{7}$

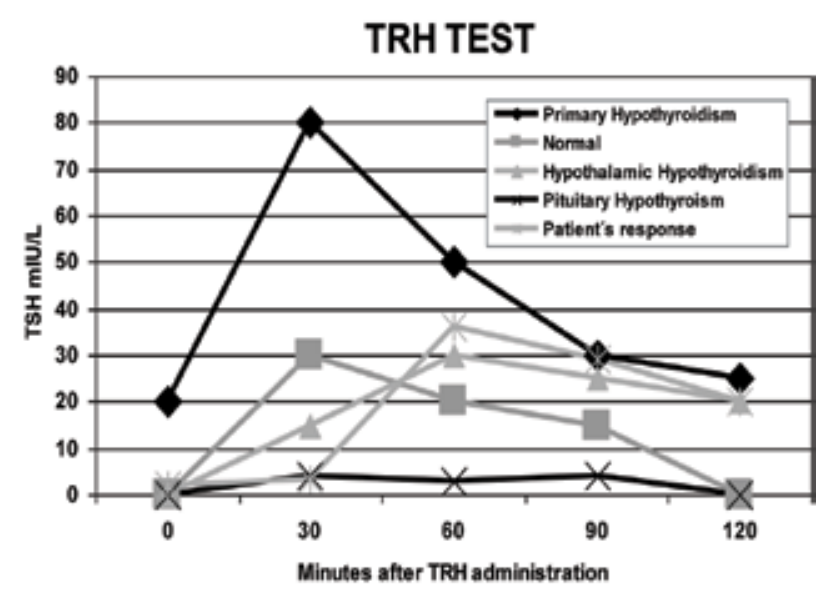

Figure 1. Thyrotropin releasing hormone (TRH) stimulation test: Variable responses depending on the diagnosis. The response in our patient is also indicated. 
insufficiently controlled and lymphocytic hypophysitis ${ }^{8}$ are included among novel causes. Growth hormone therapy is now also recognized as a possible cause of unmasking Central H. ${ }^{9}$

In addition, several rare gene mutations such as, TRH, TSH $\beta$, TRHR, POU1F1, PROP1, HESX1, SOX3, LHX3, LHX4 genes, the genes of leptin receptor (LEPR) and LEP have been associated with Central H..$^{10-14}$ Most of these genetic defects are clinically suspected, as they lead to variable phenotypes of combined pituitary hormones deficiencies and may be associated with physical abnormalities, such as septo-optic dysplasia (HESX1 mutations), hypoplasia infundibular or mental retardation (SOX3 mutations), rigid cervical spines (LHX3 mutations) and cerebellar defects or sellar abnormalities (LHX4 mutations). ${ }^{15}$ Conversely, congenital I Central $\mathrm{H}$ is mainly due to genetic deficiency of the $\beta$-subunit of TSH or less frequently to mutations of the TRH or TRH receptor genes and it is usually associated with a severe form of congenital hypothyroidism if it is not treated promptly. ${ }^{12-16}$ As our patient was an adult and had a mild hypothyroidism with normal mental development, a genetic screening was not considered necessary.

The clinical manifestations of Central $\mathrm{H}$ are similar to those of PH. As a result, with the use of the serum TSH assay as an initial screening test for thyroid disease, the diagnosis of Central $\mathrm{H}$ can be missed or delayed, because most patients have normal or even slightly high serum TSH concentrations. ${ }^{17}$ In general, serum TSH concentrations are low in pituitary disease and normal or high in hypothalamic disease, although one cannot rely upon this generalization for a pathologic diagnosis in an individual patient. Several mechanisms leading to these differences in TSH levels have been suggested: hypoadrenalism raising serum TSH levels, decreased secretion of somatostatin from the hypothalamus resulting in increased TSH secretion, and reduced biological and receptor binding activity of TSH. ${ }^{17-19}$

The diagnostic value of TRH stimulation has been evaluated in several studies. ${ }^{20-22}$ Administration of TRH (200 micrograms) to normal individuals produces a consistent rise in serum TSH levels. Peak values are seen at $15-30 \mathrm{~min}$, with notable decrease starting at $60 \mathrm{~min}$. Generally normal and pathologic responses of TSH to TRH are depicted in Figure 1. Many cases of Central $\mathrm{H}$ show either blunted or delayed patterns, as was the response in our case. A delayed serum response to TRH is a characteristic but not specific finding in patients with hypothalamic disease. Conversely, normal TRH tests also do not exclude abnormalities in the hypothalamic-pituitarythyroid axis. Moreover, most patients with Central $\mathrm{H}$ (especially hypothalamic disease) do not have the usual nocturnal TSH surge, although the validity of this approach is still controversial. ${ }^{23,24} \mathrm{~A}$ MRI should be carried out in suspected cases of Central $\mathrm{H}$ to detect hypothalamic or pituitary lession. Finally, it is very important to differentiate between Central $\mathrm{H}$ and other entities. A patient with low fT4 and slightly elevated TSH could have either PH or Central H. In this case, measurement of anti-TPO antibodies could be very useful, since they are negative in Central $\mathrm{H}$, as occurred in our case. Other differential diagnosis must be also undertaken ${ }^{25}$ after stopping T4 therapy in patients with a nodular goiter ${ }^{26}$ or in patients with severe nonthyroidal illness. In our patient, once the presence of Central H was confirmed and other entities or critical illness were excluded, and no lesion was found in the MRI and no other hormone was altered, the unusual diagnosis of idiopathic isolated Central $\mathrm{H}$ was established, possibly caused by deficient TRH synthesis. ${ }^{27}$

Because the optimum thyroxin dose for Central $\mathrm{H}$ is still unclear, ${ }^{28}$ a dose similar to that given to patients with primary hypothyroidism is recommended (after excluding ACTH deficiency). The main difference in treatment between $\mathrm{PH}$ and Central $\mathrm{H}$ is that TSH cannot be used to monitor the therapy as it is suppressed to $<0.1 \mathrm{mU} / \mathrm{L}$ in nearly all patients taking doses of $\mathrm{T} 4$ that raise their serum free $\mathrm{T} 4$ concentrations to normal. ${ }^{29}$

In conclusion, Central $\mathrm{H}$ is an uncommon disorder which is mainly due to acquired lesions and it is usually associated with deficient secretion of other pituitary hormones. The appearance of an idiopathic isolated Central $\mathrm{H}$ is extremely rare and is often misdiagnosed. As routine examination of thyroid function (TSH determination) cannot easily detect it, TSH response to TRH stimulation, nocturnal surge of TSH and exclusion of more common causes of TSH 
deficiency are needed to confirm the diagnosis. Our case is especially interesting due to the low prevalence of idiopathic I Central $\mathrm{H}$ and its initial misdiagnosis. Idiopathic isolated TSH or TRH deficiency is usually a genetic disorder diagnosed in infancy ${ }^{13}$ and the occurrence of such an entity in adulthood constitutes a novel observation. A genetic basis of an isolated TRH deficiency can not be excluded since late onset of symptoms in genetically determined disorders have been described. ${ }^{30}$ Nevertheless in I Central $\mathrm{H}$ one should consider that the TSH deficiency might represent a prodromal sign of an insipient, not yet apparent, neoplastic disorder.

\section{ACKNOWLEDGEMENTS}

We express warm thanks to Prof. J. Wass (Oxford Center of Endocrinology and Metabolism) for his encouragement to us to publish this case report.

\section{REFERENCES}

1. Hashimoto K, 1998 The etiology of isolated thyroid stimulating hormone deficiency. Intern Med 37: 231232.

2. Shuman CR, 1953 Hypothyroidism due to thyrotropin deficiency without other manifestations of hypopituitarism. J Clin Endocrinol Metab 13: 795-800.

3. Samuels MH, Ridway EC, 1992 Central hypothyroidism. Endocrinol Metab Clin North Am 21: 903-919.

4. Schneider HJ, Aimaretti G, Kreitschmann-Andermahr I, Stalla GK, Ghigo E, 2007 Hypopituitarism. Lancet 369: 1461-1470.

5. Benvenga S, Vigo T, Ruggeri RM, et al, 2004 Severe head trauma in patients with unexplained central hypothyroidism. Am J Med 116: 767-771.

6. Sherman SI, Gopal J, Haugen BR, et al, 1999 Central hypothyroidism associated with retinoid $\mathrm{X}$ receptorselective ligands. N Engl J Med 340: 1075-1079.

7. Kempers MJ, van der Sluijs Veer L, Nijhuis-van der Sanden RW, et al, 2007 Neonatal screening for congenital hypothyroidism in the Netherlands: cognitive and motor outcome at 10 years of age. J Clin Endocrinol Metab 92: 919-924.

8. Thodou E, Asa SL, Kontogeorgos G, Kovacs K, Horvath E, Ezzat S, 1995 Lymphocytic thyroiditis: clinicopathological findings. J Clin Endocrinol Metab 80: 2302-2311.

9. Agha A, Walker D, Pery L, et al, 2007 Unmasking of central hypothyroidism following growth hormone replacement in adut hypopituitary patients. Clin Endocrinol (Oxf) 66: 72-77.

10. Pfaffle RW, DiMattia GE, Parks JS, et al, 1992 Mutation of the POU-specific domain of Pit-1 and hypopituitarism without pituitary hypoplasia. Science 257: 1118-1121.

11. Collu R, Tang J, Castagne J, et al, 1997 A novel mechanism for isolated central hpothyroidism: inactivating mutations in the thyrotropin-releasing hormone receptor gene. J Clin Endocrinol Metab 82: 1561-1565.

12. Hayashizaki Y, Hiraoka Y, Tatsumi K, et al, 1990 Deoxyribonucleic acid analices of five familias with familial inherited thyroid stimulating hormone deficiency. J Clin Endocrinol Metab 71: 792-796.

13. Dacou-Voutetakis C, Feltquate DM, Drakopoulou M, Kourides IA, Dracopili NC, 1990 Familial hypothyroidism caused by a nonsense mutation in the thyroidstimulating hormone beta-subunit gene. Am J Hum Genet 46: 988-993.

14. Medeiros-Neto G, Herodotou DT, Rajan S, et al, 1996 A circulating, biologically inactive thyrotropin caused by a mutation in the beta subunit gene. J Clin Invest 97: 1250-1256.

15. Kelberman D, Dattani MT, 2007 Hypopituitarism oddities:congenital causes. Hormone Res 68: 138-144.

16. Bonomi M, Proverbio Mc, Weber G, Chiumello G, Beck-Peccoz P, Persani L, 2001 Hyperplastic pituitary gland, high serum glucoprotein hormone alpha-subunit, and variable circulating thyrotropin (TSH) levels as hallmark of central hypothyroidism due to mutations of the TSH-beta gene. J Clin Endocrinol Metab 86: 1600-1604.

17. Faglia G, Bitensky L, Pinchera A, et al, 1979 Thyrotropin secretion in patients with central hypothyroidism: Evidence for reduced biologic activity of inmunoreactive thyrotropin. J Clin Endocrinol Metab 48: 989-998.

18. Beck-Peccoz P, Amr S, Menezes-Ferreira MM, Faglia G, Weintraub BD, 1985 Decreased receptor binding of biologically inactive thyrotropin in central hypothyroidism:effect of treatment with thyrotropin-releasing hormone. N Engl J Med 312: 1085-1090.

19. Persani L, Ferretti E, Borgato S, Faglia G, Beck-Peccoz P, 2000 Circulating thyrotropin bioactivity in sporadic central hypothyroidism. J Clin Endocrinol Metab 85: 3631-3635.

20. Atmaca H, Tanriverdi F, Gokce C, Unluhizarci K, Kelestimur F, 2007 Do we still need the TRH stimulation test? Thyroid 17: 529-533.

21. Van Tijn DA, de Vijlder JJ, Vulsma T, 2008 Role of the thyrotropin-releasing hormone stimulation test in diagnosis of congenital central hypothyroidism in infants. J Clin Endocrinol Metab 93: 410-419.

22. Mehta A, Hindmarsh PC, Stanhope RG, Brain CE, Preece MA, Dattani MT, 2003 Is the thyrotropin-releasing hormone test necessary in the diagnosis of central hypothyroidism in children? J Clin Endocrinol Metab 88: 5696-5703.

23. Mönig H, Stracke L, Arendt T, Kloenhn S, 1999 Blunted nocturnal TSH surge does not indicate central hypothyroidism in patients after pituitary surgery. Exp Clin 
Endocrinol Diabetes 107: 89-92.

24. Darzy Kh, Shalet SM, 2005 Circadian and stimulated thyrotropin secretion in craneally irradiated adult cancer survivors. J Clin Endocrinol Metab 90: 6490-6497.

25. Uy HL, Reasner CA, Samuels MH, 1995 Pattern of recovery of the hypothalamic-pituitary-thyroid axis following radioactive iodine therapy in patients with Grave's disease. Am J Med 99: 173-179.

26. Vagenakis AG, Braverman LE, Azizi F, Portinay GI, Ingbar SH, 1975 Recover of pituitary thyrotropic function after withdrawal of prolonged thyroid-supression therapy. N Engl J Med 293: 681-684.

27. Sertedaki M, Voutetakis A, Dacou-Voutetakis C, 2005 Molecular defects in the hypothalamic -pituitary- thyroid axis leading to congenital hypothyroidism. Current Pediatric Reviews 1: 225-233.

28. Slawiwik M, Klawitter B, Meiser E, et al, 2007 Thyroid hormone replacement for central hypothyroidism: a randomized controlled trial comparing two doses of thyroxine (T4) with a combination of T4 and triiodotihyronine. J Clin Endocrinol Metab 92: 4115-4122.

29. Shimon I, Cohen O, Lubetsky A, Olchovsky D, 2002 Thyrotropin suppression by thyroid hormone replacement is correlated with thyroxine level normalization in central hypothyroidism. Thyroid 12: 823-827.

30. Dacou-Voutetakis C, Dracopoulou M, 2006 Non-classical congenitl adrenal hyperplasia. Pediatr Endocrinol Rev 3: Suppl 1: 195-197. 